Arab World English Journal (AWEJ) Volume 12. Number3 September 2021

DOI: https://dx.doi.org/10.24093/awej/vol12no3.33

Pp. 486-506

\title{
Agency as Rhetorical Device in the Discourse of kids Animated Learning Videos on Covid-
} 19 Virus

\author{
Lina Laith Younus \\ Department of English Language \\ College of Education for Women, University of Baghdad \\ Iraq, Baghdad \\ Corresponing Author: dr.lina@ coeduw.uobaghdad.edu.iq \\ Nahid Ra'aoof Kareem \\ Department of English Language \\ College of Education for Women, University of Baghdad \\ Iraq, Baghdad
}

Received: 6/21/2021

Accepted: 9/2/2021

Published: 9/29/2021

\begin{abstract}
At Covid-19 pandemic, people worldwide were attacked by a dangerous and widely spread virus known as Coronavirus. Kids are not matured enough to understand why they have to stay home and follow health instructions. Animated learning videos are designed for kids for the purpose of making them aware of the virus. The objectives of the present study are: (1) Examining one of Burke's pentad (1969) represented by "agency," in Covid-19 kids videos, (2) Investigating the rhetorical devices used in the selected data to inform, persuade and make kids aware of what is meant by covid-19, (3) Revealing the dominant rhetorical device. The main question that arises here is; "what are the rhetorical strategies used in the discourse of the learning videos on Covid$19^{\prime \prime}$. The selected data is limited to the discourse of six kids' videos dealing with covid-19 found on YouTube. The theories followed in the analysis are Tarigan's theory (2013) and Burke's pentad (1969). The results revealed that the discourse of each video reflects a dramatic situations, including the pentad items; act, scene, agent, agency, and purpose. It is also found that agency as a rhetorical device is highly used in the selected data and the most dominant device was personification. It is concluded that the use of the dramatic situations and rhetorical devices in such videos has a valuable role in making kids aware of what is meant by Covid-19 pandemic and persuaded why they have to follow the safety instructions, leaving schools and stay home. Keywords: Agency, Burke's pentad, Covid-19, figurative language, kids videos, Tarigan's theory

Cite as: Younus, L. L. , \& Kareem, N. R. (2021). Agency as Rhetorical Device in the Discourse of kids Animated Learning Videos on Covid-19 Virus. Arab World English Journal, 12 (3) 486506. DOI: https://dx.doi.org/10.24093/awej/vol12no3.33
\end{abstract}


Appendix E: Titles of videos and websites

\section{Introduction}

The research is a synchronic study with the time of the Covid-19 pandemic. Linguists recognized the importance of language in spreading awareness among citizens, especially children. They focus on the discourse of instructive videos that teach children the danger of the covid-19 virus and how to protect themselves and their families from this highly contagious and dangerous virus. The problem of this study comes to mimic the 2019 severe salient event. Covid19 has taken the world by storm and changed the lives of children and families. At the quarantine time, children are not going to school. They hear about the virus, but they do not know what the virus is? What are its effects on their life? To what extent is the virus dangerous? And what are the health instructions to be followed by which persons can avoid the infection of covid-19 illness? All the above questions are about brutal scientific facts; children are not mentally mature enough to understand such points. The rationale for this is to promote awareness of the virus's danger and provide kids with health instructions for protecting themselves. Leaving children without knowing the rules to protect themselves from the virus will cause them to be affected and negatively affect their families. They may be exposed to the virus disease, at the same time, transmit the virus to their families. While their knowledge of the health rules that prevent the disease of the virus, will turn them into active members in raising awareness among their colleagues and families. "We kids can contribute a lot, since we have a lot of free time now and a lot of platforms as well. We can become influencers to raise awareness about the virus", Martinaage 16, Albania-said in a study by Parra \& Stephano (2020).

Kids learning videos are part of a great media to answer the kids' questions and facilitate those complex scientific facts for kids. They tend to simplify these facts interestingly and attractively using the rhetorical strategies of the Dramatic situation of Burke's pentad (1969) resembled by "agency" and Tarigan's theory (2013) of figurative language. The research question of the current study is trying answer "what are the rhetorical strategies used in the discourse of the learning videos on Covid-19". That helps kids to understand the danger of this virus, stay home, and follow the safety instructions. The objectives of the present study are: 1) examining one of Burke's pentad (1945) represented by "agency," on Covid-19, 2) investigating the rhetorical devices used in the selected data to inform, persuade and make kids aware of what is meant by covid-19, 3) revealing the dominant rhetorical device.

Scientifically and linguistically speaking, this research has considerable significance. It will be of a significant value to; those who are interested in discourse analysis, those who are specialists in pedagogy and education, children's literature, and kids' psychology, also to the consultants who deliver scientific facts to reach kids' minds in their early years. Kids' videos will be an excellent tool to convey health messages from specialists and scientists in the medicinal field to children.

\section{Literature Review}

The outbreak of Covid-19 had a health and economic impact on the whole world. On March 11, 2020, World Health Organization [WHO] classified the COVID-19 situation as a pandemic basing on the "alarming levels of spread and severity, and by the alarming levels of inaction" (Bedford, Enria \& Giesecke, 2020.n.p.). Covid-19 has spread to 181 countries, infected 245,888 people globally and killed 10,048 (Worldometer, 2020). More than the tragic human consequences of Coronavirus, the United Nation's trade and development agency [UNCTAD] 
Appendix E: Titles of videos and websites

evaluated the "slowdown in the global economy caused by COVID-19 is likely to cost at least US\$1 trillion” (United Nations, 2020, n.p.).

As it has been appeared, across the whole world in multiple situations of crisis, social life is at the core of these circumstances. Kids have suffered during the quarantine time. They are forced to stay at home, isolated away from their friends, and prevent going to school. "Children being the most vulnerable are often the worst affected. To fight Covid19, the country is under lockdown to contain the spread of the pandemic" (Unicef for every child, n. d., n. p.). Psychosocially speaking, kids' lives are changed, " they are hit the hardest by the psychosocial impact of this pandemic. Being quarantined in homes and institutions may impose a more significant psychological burden than the physical suffering caused by the virus. School closure, lack of outdoor activity, aberrant dietary and sleeping habits are likely to disrupt children's usual lifestyle" (Ghosh, Dubey, Chatterjee \& Dubey, 2020, n. p.). Parra \& Stephano (2020) believed that "children and young people are struggling the most with this virus crisis. Children are mentally suffering, but not only this affecting us. We are badly in need of physical activities too. Children are used to moving, running, and socializing every day, and now we are confined to our rooms and houses" (p.8). They underlined in the findings of their study the significance of making kids aware of what is going on around them highlighting "the importance of recognizing children and young people's ability to understand the current crisis and the need to support meaningful spaces and partnerships with them to help them take action to reduce the spread of COVID-19" They also assisted "It's important for children to follow the main rule of stopping the virus" (p. 29).

Videos have a considerable role in spreading the awareness of following the critical rules of stopping this virus like "Watch videos from Indigenous Services Canada on available support and methods to help you stay safe, such as hand washing and physical distancing" (Awareness resources and videos, n. d., n. p). YouTube videos are attractive as they interesting in presenting educational matters, "One of the most popular screen activities for kids is watching YouTube videos for both entertainment and education" (Das. \& Dore, 2021, n. p.). Through the literature review, it is noticed that there are many studies have been dealt with the way of making videos for kids and providing kids with videos. Yet, there is no study addressed the discourse of kids' videos, especially those of Covid-19. That is the gap of this research. Recognizing the importance of language in spreading awareness among citizens, especially children, linguists focus on children's speech in instructive videos related to educating children about the danger of the covid-19 virus and how to protect themselves and their families from this highly contagious and dangerous virus.

Regarding the selected data in the current study, there is a crucial need to apply the theory of dramatic situations by Burke (1969). Burke (1969) presented his dramatic pentad in his $A$ Grammar of Motives. He derives his concept, dramatic pentad, from the world of drama; West and Turner pointed out "Drama tends to follow recognizable types or genres: comedy, musical, melodrama, and so forth. Burke feels that the very way we structure and use language may be related to the way these human dramas are played out" (West \& Turner, 2009). Burke dealt with the dramatic pentad as a means of understanding the human being's motivation which stands behind human action. Through Burke pentad, he tried to answer questions such as: What 
Appendix E: Titles of videos and websites

is involved, when we say, what people are doing, and why they are doing it? (Herrick, 2013) His pentad includes five elements. Briefly, they are:

1. The act is what has been done or what had been done, it's time.

2. The scene is the setting of the show, its location.

3. The agent is the one who is acting, while

4. The agency shows how the act is performed by the agent. Finally,

5. The purpose is the reason that stands behind the action or the intended aim (Burke, 1969).

They are most helpful when they are combined as ratios for demonstrating the dynamics of a specific rhetorical act. Dramatic ratios are defined as "proportions of one element relative to another in the Dramatism Pentad" (West \& Turner, 2009, p.336). It is used to determine the dominant element of the pentad in the interaction. Hunt (2003) named dramatic ratios the "interaction effects of two or more elements" (p. 379). The pentad could help to limit why a speaker chooses a specific rhetorical strategy of identifying with an audience (West \& Turner, 2009). When utilizing the pentad to analyze a particular symbolic interaction, researchers determine all elements of the pentad, firstly. Then, they determine what occurred for a specific act. After labeling the items of the pentad and completely explicating each. Finally, examine dramatic ratios (West \& Turner, 2009). By analyzing ratios in this way, the researcher can find out a dominant element and which element is utilized more than others? Overington (1977), "The most common ratios used by Burke are Scene-Act and Scene-Agent" (p.143).

It is crucial to study symbolic language in the context of understanding all elements of any situation. It provides a clear, insightful interpretation. One goal of using figurative language is to affect, inform and persuade the audience. Burke pentad, which is part of the rhetoric theory, also seeks to study the way the speaker can impact, inform and convince the audience but by the context of dramatic situation. The dramatic situation as discussed above with its pentad. One of the pentad elements is the agency which, according to Burke, is how the action happens. The researchers hypothesize that Covid-19 kids' videos writers use two agencies: 1) the agency of situation and 2) the agency of rhetorical devices (figures of speech). Based on that, the researchers have used the two theories in the data analysis.

Tarigan (1986) stated that figure of speech is one form of rhetoric. According to him, the figure of speech uses words in writing and speech to influence and persuade the reader and listener. Tarigan believed that figurative language is an aesthetic language that has been used to enhance and elevate the effect by presenting and arrange a particular thing or an object with other items or objects that are more popular. Using figures of speech in a language produces figurative language. It, in turn, changes the discourse from literal to nonliteral language (Findly, 1998). Tarigan (2013) argued that "figurative language is a use of beautiful words to give effect by comparing one thing with another object that is more common" (p.4).

There are reasons why writers use figurative language in their works; according to Perrine (1983), these reasons are, firstly, figurative language carries the satisfaction and imagination within its words; so, it is the source of pleasure and exercises a new way of thinking. Secondly, figures of speech bring extra imagery into sentences; they convey the abstract to concrete and 
Appendix E: Titles of videos and websites

make writing more sensuous. Thirdly, figures of speech are a medium of supplement emotional effects to otherwise merely instructing statements. Figurative language has expressions and words, their meanings different from the literal interpretation. It seeks to compose effective and aesthetic discourse. Tarigan (2013) saw figurative language as a language that imaginatively and non-literary used. It creates a new way of eying the world.

According to Perrine (1983), figurative language means saying a thing other than ordinary. It refers to the person's style in choosing creatively certain words rather than others. The figure of speech seeks to tie up a specific thing to one another. The link between these two things involves exaggeration, comparison, and saying less. McArthur (1992) viewed figurative language as how particular figures of speech like metaphors freely appear. He lighted that a figure of speech is a rhetorical device employing words in a distinctive way achieving a specific effect. Figurative language, according to Abrams (1999), is sometimes considered primarily poetic; since it integrates the function of language.

Khodijah (2010) confirmed that figurative language is represented in the implied meaning. That because the words utilized in figurative language is not the real meaning yet, it is connotative meaning. Figurative language is a statement that departs from our everyday, and literal language aims to make freshness, comparison, emphasis, clarity, or emphasis occur.

The difference between figurative language and literal language is that the meaning of literal language is as it is uttered. In contrast, figurative language is an implied meaning that is based essentially on context. Figurative language triggers the imagination and creative thinking according to various situations. Figurative language takes the reader far away from the monotonous, boring writing; the dull, boring writing makes the reader wary of completing reading a particular topic. In contrast, figurative language in writing makes the reader enjoy and longs to finish what he has begun reading.

Evans (2009) believed that the purpose of using figurative tools is to stimulate a particular image. Several goals are served by figurative devices. Figurative devices work on clarifying meaning, stimulating emotions and associations, in addition to providing vivid examples. They bring life to an inanimate object, orienting or amusing. More important is their primary aesthetic purpose, deepening and widening the range of the reader's perception and his response to the word of ideas and objects.

Figurative language can be defined as a language that deviates from a straight-forward use of words. Figurative language lights ideas, brings specific effects, and creates forceful and colorful writings (Giroux \& Williston, 1974). Figurative language is known as rhetorical figures, figures of speech, and metaphorical language (Elder, 2004). According to Elder, Figurative language is the Figures of speech that paint a picture in people's minds. They are different in name, yet which are the same thing. Commonly, figurative language is used in various forms of communication, like in daily conversation, advertisements, and articles in newspapers, poems, and novels. 
Appendix E: Titles of videos and websites

\section{Kinds of Figurative Language}

Figurative language has been categorized into two common kinds 1) tropes: they focus on meaning variations in using multi-word language structure and lexemes, and 2) schemes: they concern with the repetition of phonological, lexical, and syntactic forms (Arvius, 2003). Tarigan (1986) divided figured of speech into four groups. They are; Figure of Connection, Figure of comparison, Figure of Repetition, and Figure of Opposition

\section{Figure of Comparison}

It is a kind of figurative language which is used to find the similarities in different things. The figure of comparison is of five types as following.

(a) Simile is a comparison between two things that are basically different. Simile is expressed by the using specific words such as: resembles, like, as, similar to, or as. (b) Metaphor is an implied comparison, It is formed without using words such as like, resemble, as, etc.

(c) Personification lends the human being attributes to an idea, an animal, or an object.

(d) Allegory is a description or narrative that has another meaning under the surface.

(e) Antithesis shows the emphasis of a particular theme by locating opposed characteristics or ideas in direct contrast.

\section{Figure of Opposition}

Figure of Opposition is used to show the opposite or the contradiction of a subject or an idea in phrases or sentences. The Figure of Opposition is classified into seven kinds as follow:

(a) Hyperbole is used to achieve intensity by using an expression in extreme language or exaggeration.

(b) Litotes is one figure of speech in which an affirmative theme is produced by using the negative of its converse.

(c) Irony refers to the contrast between what is implied and what is the case or what is suggested and what is actually has been said.

(d) Oxymoron refers to a figurative device by which contradictory words are united in an expression to give it the point.

(e) Paronomasia includes a play on words where the repeated words are resemble but are not identical.

(f) Paralysis is the omission of the sentence or words for achieving the rhetorical effect.

(g) Zeugma occurs when using one word to refer to two or more words in a sentence or phrase, but just one of which is logically and grammatically applicable.

\section{Figure of Connection}

The figure of connection is used to express or show a subject matter or an idea that is strongly associated, or has a close relationship. It is divided into seven kinds as follows: (a) Metonymy is to name a person, human characteristic or institution by some attribute or objects with which it is visibly associated.

(b) Synecdoche is that figure where a part refers to the whole.

(c) Allusion is an implicit or explicit reference of events, famous masterpieces, figures, or places mythologies.

(d) Euphemism is a mild or vague expression used to hide painful or unpleasant truths.

(e) Ellipsis is a figure of speech, where an omission of parts of sentences, or words is happened. 
Arab World English Journal (AWEJ) Volume 12. Number 3. September 2021

Agency as Rhetorical Device in the Discourse of kids Animated Learning

Younus \& Kareem

Appendix E: Titles of videos and websites

(f) Inverse is a figure of speech in which a transposition of an ordinary word occurs in a sentence.

(g) Graduation is one figure of speech in which the use of last words in a sentence turned into first words in the following sentence.

\section{Figure of Repetition}

It refers to a type of figurative language, where the exact phrases or words are used repeatedly in successive clauses. The Figure of Repetition is categorized into four kinds, they are:

(a) Alliteration is the onset of more than one word in close related to the identical sound.

(b) Antanaklasis refers to the repeating of similar words, while the meaning is different.

(c) Chiasmus is one figure of speech by which the words in the first of two parallel phrases are inversed in the second.

(d) Repetition refers to the repeating of the exact phrases or words where they are placed in successive clauses.

\section{Previous Studies}

There are several previous studies which this research deals with. The first study has been conducted by Harya (2016). This study aimed at describing the kinds of figurative language found in work. The result of Harya's analysis shows that there are seventy sentences that include figurative language. It is indicated that the type which dominant figurative language in the novel Alchemist is a simile. Also, it has been deduced that figurative language has vital roles in this book.

The second study has been presented by Zia, Aziz, \& Burhansyah,(2018). It aimed to identify and analyze the kinds of figurative language in Hikayat Aceh, which is presented by Muda Balia. The result shows that the writer uses figurative language to clarify and convey his purpose via his Hikayat. It has been concluded that there are ten kinds of figurative language in Hikayat Aceh, It has been found that apheresis was the dominant figure in Hikayat Aceh.

Prasetyo (2019) is the third study. It aimed at explaining the kinds of figurative language in the Ed Sheeran's song. As a result, the researcher found four types of figurative language, and hyperbole was the dominant figure used in the song.

The fourth study is by Wijayanti (2017). It aimed at; identifying and describing the kinds of figurative language in the Adultery novel, showing the dominant sort of figurative language found in the Adultery novel, and finding the non-dominant sort of figurative language found in Adultery novel. As a result, the study showed that there are four kinds of figurative languages found in the Adultery novels. Personification was the dominant figure used in the Adultery novels. And the non-dominant figure is chiasmus.

The fifth study is by Ekasani, (2015). It aimed at identifying the kinds of figurative expressions used in work. The finding showed that the figurative expressions in the novel are divided into different groups, which were:

(a) Comparison involves simile, personification, and metaphor.

(b) Contradiction involves hyperbole, and finally

(c) Connection involves allusion and metonymy.

But among these kinds of figurative expression, personification is commonly used in the novel. 
The sixth is by Nurrahmi \& Irawan (2018). The research aimed at analyzing the using of figurative language in the text of newspaper. The analyzing result revealed that the most figurative language kind used was the metaphor in the selected texts. The seventh study is by Nurhaida (2017). It aimed at identifying the type of figurative language in Online Padang Express Newspaper in March until May 2016 editions. From analyzing results, it has been deduced that the dominant language found in newspapers, "Padang Express Online", was metaphor.

The eighth study is by Maula (2013). This study aimed to identify the types of figurative language found in the poems, particularly in William Blake's poetry. The results showed that there were eleven types of figurative language found in the William Blake's poetry, and; the most frequently used was Hyperbole. From all the above, it has been concluded that the whole previous studies from various aspects agree upon having figurative language. Still they do not agree on the most commonly used one.

\section{Methodology}

The current study applies descriptive qualitative research. The researchers are interested in finding the kinds of figures of speech derived from the agency element of pentad in the discourse of kids' videos dealing with covid-19. The whole data sources have been taken from the internet, specifically from YouTube. Six kids' videos have been taken to be the sample of covid-19 kidsvideos. YouTube is selected to be the research tool as the targeted data are the discourse of kids' videos. YouTube has considerable effect on children behaviors. At the time they are watching videos, kids live a real circumstances using their eyes and ears. Social learning theory confirms that "children and adolescents learn by observing and imitating what they see on the screen, particularly when these behaviors seem realistic or are rewarded (Bandura, 1994, pp. 61-90).

Techniques have been used in analyzing data is accomplished by following steps:

(a) Electing the data (videos) from YouTube due to two criteria: 1) being deals with kids and 2) being deals with covid-19.

(b) Transcribing the selected videos into written texts using the DIY Caption program.

(c) Identifying the agency element of the pentad and the figures of speech found in the discourse of kids videos concerning covid-19.

(d) Classifying the figures of speech on the discourse of kids' videos concerning covid-19 such as metaphor, simile, and personification (Tarigan, 1986).

(e) Determining the dominant figure of speech in the selected data.

(f) Making a conclusion grounded on the data analysis of figurative language.

(g) Summarizing the findings by tabulating the results.

\section{The Data Analysis and Results}

The first part of the data analysis is due to the agency of situation as one type of Burke pentad element, agency:

Video (1): entitled Coronavirus Outbreak | How did it start? (Dr. Panda Toto Time, 2020), the pentad element is: 
Arab World English Journal (AWEJ) Volume 12. Number 3. September 2021

Agency as Rhetorical Device in the Discourse of kids Animated Learning

Younus \& Kareem

Appendix E: Titles of videos and websites

Agency

The interesting way in which Dr. Panda shows the scientific facts associated with actual photos of wildlife animals especially bats.

The dominant ratio, in this video, is scene-act since there are many scientific facts to be known by kids. Dr. Panda tries to provide kids with them.

Video (2): How to protect your kids from coronavirus? (Daily medical information, 2020) the pentad element is:

Agency

How kids can defend their home, is by cleaning everything, wash their hands frequently, and eating fruits and vegetables to strengthen their immune system.

The dominant ratio in this video is purpose-act since the primary goal of children is protecting the castle that motivates them to follow the health instruction in order to defeat their enemy.

Video (3): entitled as Coronavirus (Baby Toon TV, 2020), the pentad element is:

\section{Agency}

Knowing the magic rules, helps to fight coronavirus, is the agency of this situation. They are; staying home and washing hands with soap.

The dominant ratio, in this video, is scene-act. The scene outside (monster) motivates Silika to direct her lovely cat to follow the magic rules of protection.

Video (4): "COVID -Safe \#BacktoSchoolABCs " (MSFCares, 2020) the element of pentad is: Agency

Through the steps of $\mathrm{A}, \mathrm{B}$, and $\mathrm{C}$ involving checking their temperature frequently, washing their hands each hour with soap, and maintaining a social distance inside the classroom, children can achieve their goals in beating COVID-19.

The dominante ratio, is scene-act. The scene of returning to school when COVID-19 is still widespread motivates children to apply the healthy steps taken by school staff.

Video (5): entitled "I'm a Vaccine" (Johns Hopkins Bloomberg School of Public Health, 2020) Agency

Producing a safe and effective vaccine is the agency by which the world gets rid of COVID-19.

The dominate ratio is agency-act. Finding out a covid-19 vaccine motivates scientists to try their best to produce an effective and safe vaccine for getting rid of coronavirus.

Video (6): entitled "What is Coronavirus?" (Ineqe Safeguarding Group, 2020).

The pentad element is:

\section{Agency}

Providing kids with scientific facts of coronavirus, supporting their knowledge by many tips as well, is the way to keep them safe due to this video.

The dominant ratio is scene-act. Coronavirus is all over the news and social media at the moment. This leads to providing kids with actual facts about coronavirus and giving kids pieces of advice.

Concerning Burke pentad, the results of data analysis reveal that the writers of Covid-19 kids videos use two kinds of agencies: 1) the agency of situation and 2) the agency of rhetorical 
Appendix E: Titles of videos and websites

devices (figures of speech). It has been found that the most common ratio used in these kinds of videos is Scene-Agent that agrees with what has been mentioned, in the literature review, by Overington (1977), "The most common ratios used by Burke are Scene-Act and Scene-Agent" (p.143).

The second part of the analysis discusses the agency of figures of speech represented by their four kinds. They are; the figurative language of comparison (metaphor and personification), opposition (Hyperbole, Oxymoron, and Irony), connection (metonymy, understatement, and hyporphora), and repetition (Alliteration, Consonance, Onomatopoeia, Anaphora, Epizeuxis, and Assonance).

\section{Comparison Figures of Speech}

They include metaphor and personification. Depending on data analysis, the researchers find 39 or $50.6 \%$ data that use the figures of comparison from 77 or $100 \%$ data of figures of speech found in kids' videos concerning covid-19

Personification

There are 37 or $48 \%$ data of personification from 77 data of comparison figurative language. From datum analysis, the following examples are selected:

In the video (2), How to protect your kids from coronavirus?

The writer utilizes the words, $\underline{\text { sneak }}$ and sneaky that concerned with human attributes.

Thus, it is a personification.

"You know, germs are also very sneaky. They can sneak into you" (Daily medical information, 2020).

\section{Metaphor}

There are two or $2.6 \%$ data of personification from 77 data of comparison figurative language. In The video (3): entitled Coronavirus, the writer uses the figure, metaphor in which two different things are compared one to another, for instance:

"The monster is following us. It's ugly". (Coronavirus)

"There's a crown on his head. Let's run away from here!" (The shape of coronavirus) (Baby Toon TV, 2020). The previous data analysis has been tabled in Appendix A.

\section{Opposition Figures of Speech}

They include Hyperbole, Oxymoron, and Irony. Depending on the data analysis, the researchers find 8 or $10.4 \%$ of opposition figures of speech from 77 or $100 \%$ data of figures of speech found in kids' videos relating to covid-19.

Hyperbole

It has been identified two or $2.6 \%$ data of hyperbole from 77 data used as figurative language. The following example has been taken from the datum analysis:

In Video (1): Coronavirus Outbreak | How did it start? There is an exaggeration in the way the scientific fact is presented in the example below:

"what's even more amazing is that after many years of evolution, bats can almost perfectly repair their DNA" (Dr. Panda TotoTime, 2020). 
Arab World English Journal (AWEJ) Volume 12. Number 3. September 2021

Agency as Rhetorical Device in the Discourse of kids Animated Learning

Younus \& Kareem

Appendix E: Titles of videos and websites

Irony

There are five or $6.5 \%$ data of irony from 77 data used as figurative language. The following example has been taken from the datum analysis:

In the video three: entitled Coronavirus the speaker's words intends to express a meaning that is opposite of the said words .

"The monster is following us. It's ugly".

In the above example, the writer uses; it is ugly while he knows that coronavirus is very tiny that it cannot be seen by eyes (Baby Toon TV, 2020).

\section{Oxymoron}

There is one or $1.3 \%$ data of Oxymoron from 77 data used as figurative language. The following example has been taken from the datum analysis:

In the video three: entitled Coronavirus, the writer uses Oxymoron, A device in which two paradox words are achieved by the deliberate use of antonyms.

"Corona: I'm a "Corona" mate

Coming into the day at the night" (Baby Toon TV, 2020). The previous data analysis has been tabled in Appendix B.

\section{Connection (Linkage) Figures of Speech}

There are three types of connection figurative language they are metonymy, understatement, and hyporphora. Depending on data analysis, the researcher finds five or $6.5 \%$ data of connection figurative language from 77 or $100 \%$ data of figures of speech used in kids' videos concerning Covid-19.

\section{Metonymy}

There is one or $1.3 \%$ data of metonymy from 77 data of connection figurative language. It is a device that involves a concept or thing has been pointed to indirectly by naming something closely associated with it .

In the video four: entitled COVID-Safe \#BacktoSchoolABCs metonymy is represented in :

"ABCs are what we need".

Singing kids indicate by ABCs: A is for actions they can do. B is for them to behave, and $\mathrm{C}$ is their classrooms (MSFCares, 2020).

\section{Understatement}

There are three or $3.9 \%$ data of understatement from 77 data of connection figurative language found in kids videos concerning covid-19. A device that makes the idea less significant than it is .

In the video three: entitled Coronavirus, there is the following:

"I've just known something new about our enemy germs

They can fly

Don't worry if you wear this magical protective mask

When you're walking in a crowd, they can't get into you" (Baby Toon TV, 2020). 
Arab World English Journal (AWEJ) Volume 12. Number 3. September 2021

Agency as Rhetorical Device in the Discourse of kids Animated Learning

Younus \& Kareem

Appendix E: Titles of videos and websites

Hypophora

There is one or $1.3 \%$ data of hypophora from 77 data of connection figurative language found in kids' videos concerning covid-19. It is a rhetorical device where the speaker asks a question. Then, he proceeds to answer it .

In the video six: entitled what is Coronavirus? Is:

"Can you guess how many copies of me would fit onto the end of a tiny in? Well, the answer is millions and millions of viruses" (Ineqe Safeguarding Group, 2020). The previous data analysis has been tabled in Appendix C.

\section{Repetition Figurative Language}

There are six types of Repetition figurative language are Alliteration, Consonance, Onomatopoeia, Anaphora, Epizeuxis, and Assonance. Depending on data analysis, the researcher finds 25 or $32.5 \%$ data of connection figurative language from 77 or $100 \%$ data of figures of speech used in kids' videos concerning covid-19.

\section{Alliteration}

There are five or $6.5 \%$ data of alliteration from 77 data of connection figurative language found in kids' videos concerning covid-19. It is a device where usually consonant sounds are repeated at the beginning of two or more neighboring syllables or words .

In the video five: entitled "I'm a Vaccine"', the following example has been taken.

"So you could cure Covid" (Johns Hopkins Bloomberg School of Public Health, 2020).

\section{Consonance}

There are four or $5.2 \%$ data of consonance from 77 data of connection figurative language found in kids' videos concerning covid-19. It is a device where consonant sounds have been repeated across words; it appears at any place within the term. In the video five entitled "I'm a Vaccine." the following example has been taken.

"With some virus detective and we could wipe out COVID Vaccine if I'm safe and effective" (Johns Hopkins Bloomberg School of Public Health, 2020).

\section{Assonance}

There are eight or $10.4 \%$ data of assonance from 77 data of connection figurative language found in kids videos concerning covid-19. Assonance points to the vowel rhyme where a vowel sound is repeated in a sentence creating an internal rhyme.

In the video (4): entitled COVID-Safe \#BacktoSchoolABCs, assonance has been represented in ABCs is what we need COVID-19 we will beat (MSFCares, 2020).

\section{Onomatopoeia}

There are two or $2.6 \%$ data of Onomatopoeia from 77 data of connection figurative language found in kids' videos concerning covid-19. It is the use of words that attempt to mimic a sound. In the video six: entitled What is Coronavirus? The following examples are taken "If you feel hot or start coughing ahhm, ahhm"(Ineqe Safeguarding Group, 2020)

\section{Anaphora}

There is one or $1.3 \%$ data of anaphora from 77 data of connection figurative language found in kids' videos concerning covid-19. 
Arab World English Journal (AWEJ) Volume 12. Number 3. September 2021

Agency as Rhetorical Device in the Discourse of kids Animated Learning

Younus \& Kareem

Appendix E: Titles of videos and websites

In the video four entitled COVID-Safe \#BacktoSchoolABCs, The exact words have been repeated in the initial of successive sentences, so it has been identified as anaphora:

ABCs are what we need COVID-19, we will beat (MSFCares, 2020).

\section{Epizeuxis}

There are five or $6.5 \%$ data of Epizeuxis from 77 data of connection figurative language found in kids' videos concerning covid-19. It is the repetition of the identical word without any interruption.

In the video two: entitled How to protect your kids from coronavirus? In the following example: "Rub Rub and Rub with soap and water for twenty seconds" (Daily medical information, 2020). The previous data analysis has been tabled in Appendix D.

This research aims at investigating figures of speech in the discourse of kids' videos on Covid-19 according to Tarigan theory which classified the figures of speech into four types. The researcher has found 77 sentences that involve figures of speech; the findings can have been summarized tabling as the following:

Table1. Frequencies and the Percentages of the figures of speech found in kids' videos concerning COVID-19

\begin{tabular}{|c|c|c|}
\hline & & \\
Figures of speech & Frequency & Percentage \\
\hline Personification & 37 & $48 \%$ \\
\hline Assonance & 8 & $10.4 \%$ \\
\hline Metaphor & 2 & $2.6 \%$ \\
\hline Consonance & 4 & $5.2 \%$ \\
\hline Anaphora & 1 & $1.3 \%$ \\
\hline Hyperbole & 2 & $2.6 \%$ \\
\hline Understatement & 3 & $3.9 \%$ \\
\hline Epizeuxis & 5 & 6.5 \\
\hline Alliteration & 5 & $6.5 \%$ \\
\hline Irony & 2 & $6.5 \%$ \\
\hline Onomatopoeia & 1 & $2.6 \%$ \\
\hline Hypophora & 1 & $1.3 \%$ \\
\hline Metonymy & 1 & $1.3 \%$ \\
\hline Oxymoron & 77 & $1.3 \%$ \\
\hline Total & 5 & $100 \%$ \\
\hline
\end{tabular}

Data analysis shows that there are four types of figures of speech, namely Repetition figurative language, Comparison figures of speech, Repetition figurative language, Opposition figures of speech, Connection (Linkage) figures of speech. The researchers find all these types in the discourse of (Covid19) kids' videos. Concerning the comparison figures of speech and depending on data analysis, the researchers find 39 or $50.6 \%$ data that use the figures of comparison from 77 or $100 \%$ data of figures of speech found in kids videos concerning covid-19. In contrast opposition figures of speech scores find eight or $10.4 \%$ data of opposition figures of speech from 77 or $100 \%$ data of figures of speech found in kids' videos relating to covid-19. Connection (Linkage) figures of speech score five or $6.5 \%$ data of connection figurative language from 77 or $100 \%$ data of figures of speech used in kids videos concerning covid-19. And repetition figurative language scores 25 or $32.5 \%$ data of connection figurative language 
Arab World English Journal (AWEJ) Volume 12. Number 3. September 2021

Agency as Rhetorical Device in the Discourse of kids Animated Learning

Younus \& Kareem

Appendix E: Titles of videos and websites

from 77 or $100 \%$ data of figures of speech used in kids' videos concerning covid-19. Among these types of figurative language, there is a type that is commonly most used. It is the comparison figures of speech with 39 or $50.6 \%$. The less scoring is by Connection (Linkage) figures of speech with five or $6.5 \%$.

Within these kinds of figurative language, personification is the dominant figure with 37 times or 48\%; this result agrees with the fourth study is by Wijayanti (2014) and with the fifth study by Ayu (2016) the fewer dominant figures are; Oxymoron, Metonymy, Hypophora and Anaphora, each they score one or $1.3 \%$.

\section{Discussion}

Rhetorical devices, especially personification, play an essential role in building the structure of kids' videos discourse. Using these devices attracts kids attention, they fasten kids learning, as well as, they widen their thinking and developing their ability of receiving concepts. The kids' videos discourse writers used rhetorical devices, particularly, personification as it is represented by animals or things that are loved by children. Animals behave as if they are people; live in similar rooms and houses, and have a family like that of children. Children who are watching such video, they-as if-at the same time live a real social environment. So, rhetorical devices are a close medium that in a lovely way conveys ideas and concepts as well as information, to children. This study contributes in spreading awareness of the danger of the Coronavirus disease in society, especially among children.

Harya's (2016) study shows that there are seventy sentences that include figurative language. It is indicated that the type which dominant figurative language in the novel Alchemist is a simile. While the present study shows seventy seven rhetorical devices. And the dominant one is personification. This difference is expectable as the former deals with a text of a book while the later deals with a video discourse. Yet, both of them have rhetorical devices in their linguistic structures. The second study which is by Zia, Aziz, \& Burhansyah, (2018). It has been concluded that there are ten kinds of figurative language in Hikayat Aceh, It has been found that apheresis was the dominant figure. While the present study shows seventy seven rhetorical devices. And the dominant one is personification. This difference is expectable as the former deals with a text of a novel while the later deals with a video discourse.

Prasetyo (2019) finds four types of figurative language, and hyperbole is the dominant figure used in the song. This study finds seventy seven rhetorical devices. Yet both; the song and kids videos contain rhetorical devices. Prasetyo deals with one unit which is a song while, this study deals with six units which are kids' videos. That's makes the number of rhetorical devices disparate. Also, there is a deferent in the dominant rhetorical device kind; hyperbole in the former and personification in the later.

The fourth study which is by Wijayanti (2017) shows that there are four kinds of figurative languages found in the Adultery novels. Personification is the dominant figure used in the Adultery novels. While the present study shows seventy seven rhetorical devices. Yet, both works have the same dominant rhetorical device which is personification. It indicates that both works' writers seek to raise the imaginary of the recipients.

The fifth study is by Ekasani, (2015) agrees widely with this study showing that the figurative expressions in the novel are divided into diverse groups; comparison, contradiction, and 
Appendix E: Titles of videos and websites

connection, among these kinds of figurative expression, personification is commonly used in the novel. Data analysis of the present study likewise shows that there are four types of figures of speech, which are; repetition figurative language, comparison figures of speech, repetition figurative language, opposition figures of speech, and connection (Linkage) figures of speech. The researchers find all these types in the discourse of (Covid-19) kids' videos. In parallel, the common rhetorical devices in kids' videos are personification.

Nurrahmi \& Irawan (2018) reveals that the most figurative language kind used was the metaphor in the selected texts. While, this study find out that the common rhetorical device is personification. Writing discourse for kids varies from writing for adults, though both works uses rhetorical devices, but it appears-through the research analysis- that personification is more related to kids' videos.

The seventh study is by Nurhaida (2017), it has been deduced that the dominant language found in newspapers, "Padang Express Online", is metaphor. The present study finds out that the dominant rhetorical device is personification. Newspapers, as data, are different from kids 'videos. That is because of the difference in the age of the recipients.

The eighth study is by Maula (2013) shows that there are eleven types of figurative language found in the William Blake's poetry, and; the most frequently used is Hyperbole. While the present study shows seventy seven rhetorical devices. And the dominant one is personification. This difference is expectable as the former deals with Blake's poetry, while the later deals with a video discourse. Yet, both of them have rhetorical devices in their discourse. From all the above, it has been concluded that the whole previous studies from various aspects agree upon having figurative language. Still they do not agree on the most commonly used one.

The problem of this study comes to mimic the 2019 severe salient event. Covid-19 has taken the world by storm and changed the lives of children and families. At the quarantine time, children are not going to school. They hear about the virus, but they do not know what it is the virus? What are its effects on their life? To what extent is the virus dangerous? And what are the health instructions to be followed by which persons can avoid the infection of covid-19 illness? All the above questions are about brutal scientific facts; children are not mentally mature enough to understand such points. Kids learning videos are part of a great media to answer the kids' questions and facilitate those complex scientific facts for kids. Through the literature review and the previous studies, it is deduced that there is a gap in investigating the rhetorical devices in kids' videos, especially, that videos on Covid-19. The researchers have not found any study that dealt with rhetorical devices in kids' videos discourse on Covid-19. Also, they have not found any research that dealt with rhetorical devices as an agency of dramatic situation, what makes the present study's researchers looking forward to study the Agency as Rhetorical Device in the Discourse of kids Animated Learning Videos on Covid-19 Virus.

\section{Conclusion}

In the light of the analysis results, it has been revealed that the discourse of each video reflects a complete dramatic situation matching Burcke's pentad theory and focusing on one of its elements named agency. The authors used both types of agency; agency of situation and agency of rhetorical device (figures of speech). It functions as a means of rhetorical devices of informing and persuading kids to follow the health and safety instructions. That has achieved the first aim which is examining one of Burke's pentad (1945) represented by "agency," in Covid-19 kids 
Appendix E: Titles of videos and websites

videos. The authors of such videos focus on the rhetoric device, particularly; the most frequently used one, "personification." It has a valuable role in simplifying the concept of the Covid-19 virus by giving it the human being properties or the attributes of an animate creature like monsters or any other evil creatures to make kids feel the danger of such virus and be careful about their health. That makes the second and the third aims come to be achieved. They are; investigating the rhetorical devices used in the selected data to inform, persuade and make kids aware of what is meant by covid-19 and revealing the dominant rhetorical device. To conclude, in a nutshell, the language with all its different rhetoric strategies functions as a magic instrument in the hand of the message sender to affect the receiver in either a positive or negative way.

\section{About the Authors:}

Dr. Lina Laith Younus: A Ph.D. holder of English Language/Linguistics from University of Baghdad/ College of Arts. She is an Assistant Professor in linguistics/ English language at the University of Baghdad/ College of Education for Women/ department of English Language. A peer reviewer certified from Publon Academy. She is concerned with discourse analysis, critical discourse analysis and pragmatics. https://orcid.org/0000-0001-5219-2460

Nahid Ra'aoof Kareem: M.A. Candidate in Department of English Language, University of Baghdad, College of Education for Women. She has an interest in linguistics, pragmatics and discourse analysis. She is interested in kids' literature, kids' social, healthy, and educational problems and the means of protecting them from these problems. https://orcid.org/0000-00029067-0205

\section{Reference}

Abrams, M. H. (1990). A Glossary of Literary Terms. The United States of America. Heinle and Heinle.

Arvius, A. C. (2003). Figures of Speech. Sweden. Lund: Student literature Awareness resources and videos (n. d.). Government of Canada. Retrieved from https://www.sacisc.gc.ca/eng/1603132339009/1603132369373

Baby Toon TV. (2020). Coronavirus [YouTube] Retrieved From https://youtu.be/-yNidtlVLEs mass communication. In J. Bryant \& D. Zillmann (Eds.), Media effects: Advances in theory and research (pp. 61-90). Lawrence Erlbaum Associates, Inc. Social

Bedford, J., Enria, D. \& Giesecke, J. (2020). COVID-19: Towards Controlling of a Pandemic. Comment. The Lancet. Retrieved from https://www.thelancet.com/journals/lancet/article/PIIS0140-6736(20)30673-5/fulltext

Burke, K. (1969). A Grammar of Motives. University of California Press

Daily Medical Information. (2020). How to protect your kids from coronavirus[YouTube]. Retrieved From https://youtu.be/x83ikJS78Lw

Das, B.H.\& Dore, R.(2021). Kids as young as 3 years old think YouTube is better for learning than other types of video. The Conversation. Retrieved from https://theconversation.com/kids-as-young-as-3-years-old-think-youtube-is-better-forlearning-than-other-types-of-video-150323

Panda TotoTime. (2020). Coronavirus Outbreak| How did it start? [YouTube]. Retrieved From https://www.youtube.com/watch?v=AahAQkD_uQ4

Elder, J. (2004). Exercise Your Reading Skills. New York: McGraw Hill. 
Arab World English Journal (AWEJ) Volume 12. Number 3. September 2021

Agency as Rhetorical Device in the Discourse of kids Animated Learning

Younus \& Kareem

Appendix E: Titles of videos and websites

Ekasani, A. (2015). The Use of Figurative Expression in Novel the Doomsday Conspiracy by Sidney Sheldon. International Journal of Linguistics Literature and Culture 1(1),38 DOI:10.21744/ijllc.v1i1.104

Evans, V. (2009). How words mean: lexical concepts, cognitive models, and meaning construction. Oxford: Oxford University Press.

Findlay, M. S. (1998). Language and communication: A cross-cultural encyclopedia.

Santa Barbara, Calif: ABC-Clio

Ghosh, R., Dubey, M. J., Chatterjee, S., \& Dubey, S.(2020), Impact of COVID-19 on children: special focus on the psychosocial aspect. Minerva Pediatrica June;72(3),pp.226-35 Retrieved from DOI: 10.23736/S0026-4946.20.05887-9

Giroux, J. A., \& Williston, G. R. (1974). Appreciation of Literary Forms. Rhode Island: Jamestown Publishers.

Harya, D.T. (2016). An analysis of figurative languages used in coelhos's novel. Premise: Journal of English Language and Applied Linguistics, 5(2), 45-63. Retrieved from https://ojs.fkip.ummetro.ac.id/index.php/english/article/view/815

Hunt ,S.B. (2003). An essay on publishing standards for rhetorical criticism, Communication Studies, 54 (3), 378-384, DOI: 10.1080/10510970309363295

Ineqe Safeguarding Group. (2020). What is Coronavirus?[YouTube]. Retrieved from https://www.youtube.com/watch?v=FqaXBtSaiUE

Johns Hopkins Bloomberg School of Public Health. (2020). I'm a Vaccine [YouTube]. Retrieved From https://www.youtube.com/watch?v=ITIF-i40dto

Khodijah, D.S. (2010). The Figurative Language of Nirvana's Song. Cirebon. Syekh Nurjati State Institute for Islamic Studies.

Maula, M.(2013). An analysis of figurative language on the poems entitled "Classic poetry series by William Blake", (Published Master's thesis). Cirebon: English education department of tarbiyah faculty of syekh nurjati state institute for Islamic studies. Retrieved from https://core.ac.uk/download/pdf/147420716.pdf

McArthur, T. (ed.). 1992. The Oxford Companion To The English Language. New York: Oxford University Press.

MSFCares.(2020). COVID-Safe \#BacktoSchoolABCs [YouTube]. Retrieved from https://youtu.be/iGMJBahJXCo

Nurhaida, L.M. (2017). An analysis of figurative language in views (opinion column) of online padang ekspres. E-journal english language and literature, 6(1), 45-52. https://doi.org/10.24036/ell.v6i1.8547

Nurrahmi \& Irawan, A.M.( 2018, Augest). The Analysis of Figurative Language Used in Opinion Section of The Jakarta Post Online Newspaper in Presenting Religious Defamation Issue. International journal of linguistics and humanities, 1(1),1-15.Retrieved from

https://scholar.google.com/citationsview_op=view_citation\&hl=en\&user=y4v9WPEAA AAJ\&citation_for_view=y4v9WPEAAAAJ:9yKSN-GCB0IC

Overington. A. M (1977). Kenneth burke and the method of dramatism. Theory and society, 4, 131-156. Retrieved from pdfshrdtychqw.pdf

Parra, P.C.\& Stephano, M.(2020). Children's voices in the time of COVID-19: Continued child activism in the face of personal challenges. World Vision International. Retrieved from https://www.wvi.org/publications/report/child-participation/childrens-voices-time-covid19-continued-child-activism 
Arab World English Journal (AWEJ) Volume 12. Number 3. September 2021

Agency as Rhetorical Device in the Discourse of kids Animated Learning

Younus \& Kareem

Appendix E: Titles of videos and websites

Perrine, L. \& Arp,T.A. (1983). Literature: structure, sound, and sense. New York: Harcourt Brace Jovanovich

Prasetyo, A. B. ( 2019). Figurative language used in The Ed Sheeran's song, (bachelor degree research). universitas muhammadiyah Surakarta[Muhammadiyah university of Surakarta]. Retrieved from publication article_2.pdf

Tarigan, H.G. (1986). Pengajaran semantic[semantic teaching ]. Bahasa. Bandung: Angkasa

Tarigan, H.G. (2013). Pengajaran gaya Bahasa [Language style teaching]. Bandung: Angkasa Bandung

Unicef for every child. (n.d). Psychosocial Support for Children during COVID-19 A Manual for Parents and Caregivers. Child Line. Retrieved from *PowerPoint Presentation (unicef.org)

United Nations. (2020). This is How Much the Coronavirus Will Cost The World's Economy, According to The UN. World Economic Forum. Retrieved from https://www.weforum.org/agenda/2020/03/coronavirus-covid-19-cost-economy-2020-untrade-economics-pandemic/

West, R., \& Turner, L.( 2009). Introducing Communication Theory: Analysis and Application. McGraw-Hill.

Wijayanti, L. A. (2017). An analysis of figurative language used in paulo coelho's adultery novel (2014), (Published Master's thesis). English department graduate school universitas muhammadiyah Surakarta. Retrieved from publication article.pdf

World Childhood Foundation, End Violence Against Children \& Unicef for every child.(2020).Retrieved from file:///C:/Users/Orbit/Downloads/COVID-19-and-ItsImplications-for-Protecting-Children-Online.pdf

Worldometer. (2020). COVID-19 Coronavirus Outbreak. Retrieved from https://www.worldometers.info/coronavirus/

Zia, P. K., Aziz, Z.A., \& Burhansyah, B.(2018). Analysis of Figurative Language in Hikayat Aceh Written by Muda Balia. Research in English and Education Journal, 3 (4), 231242. Retrieved from http://jim.unsyiah.ac.id/READ/article/view/11458

\section{Appendices}

Appendix A: Comparison figure of speech

\begin{tabular}{|r|r|r|l|}
\hline $\begin{array}{l}\text { Comparison figure } \\
\text { of speech }\end{array}$ & Frequency & Percentage & Examples \\
\hline Personification & 37 & $48 \%$ & $\begin{array}{l}\text { In the video (2), How to protect your kids from } \\
\text { coronavirus? } \\
\text { The writer utilizes the words, sneak and sneaky that } \\
\text { concerned with human attributes. Thus, it is a } \\
\text { personification. } \\
\text { "You know, germs are also very sneaky. They can } \\
\text { sneak into you" (Daily medical information, 2020). }\end{array}$ \\
\hline Metaphor & 2 & $2.6 \%$ & $\begin{array}{l}\text { In The video (3): entitled Coronavirus, the writer uses the figure, } \\
\text { metaphor in which two different things are compared one to } \\
\text { another, for instance: } \\
\text { "The monster is following us. It's ugly". (Coronavirus) }\end{array}$ \\
\hline Total & 39 & $50.6 \%$ & $\begin{array}{l}\text { "There's a crown on his head. Let's run away from here!"(The } \\
\text { shape of coronavirus) (Baby Toon TV, 2020) }\end{array}$ \\
\hline
\end{tabular}


Arab World English Journal (AWEJ) Volume 12. Number 3. September 2021

Agency as Rhetorical Device in the Discourse of kids Animated Learning

Younus \& Kareem

Appendix E: Titles of videos and websites

Appendix B: Opposition Figures of Speech

\begin{tabular}{|c|c|c|c|}
\hline $\begin{array}{c}\text { Opposition Figures } \\
\text { of Speech }\end{array}$ & Frequency & Percentage & Examples \\
\hline Hyperbole & 2 & $2.6 \%$ & $\begin{array}{c}\text { In Video (1): Coronavirus Outbreak / How did it start? There is an } \\
\text { exaggeration in the way the scientific fact is presented in the } \\
\text { example below: } \\
\text { "what's even more amazing is that after many years of evolution, } \\
\text { bats can almost perfectly repair their DNA" (Dr. Panda TotoTime, } \\
\text { 2020). }\end{array}$ \\
\hline Oxymoron, & 1 & $1.3 \%$ & $\begin{array}{c}\text { In the video three: entitled Coronavirus, the writer uses } \\
\text { Oxymoron, A device in which two paradox words are achieved } \\
\text { by the deliberate use of antonyms. } \\
\text { "Corona: Im a "Corona" mate }\end{array}$ \\
\hline Irony & 5 & $6.5 \%$ & $\begin{array}{c}\text { In the video three: entitled Coronavirus the speaker's words } \\
\text { Coming into the day at the night" (Baby Toon TV, 2020). } \\
\text { "The monster is following us. It's ugly". }\end{array}$ \\
\hline Total & 8 & $10.4 \%$ & $\begin{array}{c}\text { In the above example, the writer uses. It is ugly while he knows } \\
\text { that coronavirus is very tiny that it cannot be seen by eyes (Baby } \\
\text { Toon TV, 2020). }\end{array}$ \\
\hline
\end{tabular}

Appendix C: Connection figure of speech

\begin{tabular}{|r|r|r|l|}
\hline $\begin{array}{r}\text { Repetition figure } \\
\text { of speech }\end{array}$ & Frequency & Percentage & \multicolumn{1}{|c|}{ Examples } \\
\hline Alliteration & 5 & $6.5 \%$ & $\begin{array}{l}\text { In the video five: entitled "I'm a Vaccine"', the following example has } \\
\text { been taken. } \\
\text { "So you could cure covid" (Johns Hopkins Bloomberg School of } \\
\text { Public Health, 2020). }\end{array}$ \\
\hline Consonance & 4 & $5.2 \%$ & $\begin{array}{l}\text { In the video five entitled "I'm a Vaccine." the following example has } \\
\text { been taken. } \\
\text { "With some virus detective and we could wipe out COVID Vaccine if } \\
\text { I'm safe and effective" (Johns Hopkins Bloomberg School of Public } \\
\text { Health, 2020) }\end{array}$ \\
\hline Onomatopoeia & 2 & $2.6 \%$ & $\begin{array}{l}\text { In the video six: entitled What is Coronavirus? The following } \\
\text { examples are taken } \\
\text { "If you feel hot or start coughing ahhm, ahhm" (Inequ Safeguarding } \\
\text { Group, 2020) }\end{array}$ \\
\hline Epizeuxis & 1 & $1.3 \%$ & $\begin{array}{l}\text { In the video four entitled COVID-Safe \#BacktoSchoolABCs, The } \\
\text { exact words have been repeated in the initial of successive sentences, } \\
\text { so it has been identified as anaphora: } \\
\text { ABCs are what we need COVID-19, we will beat (MSFCares, 2020). }\end{array}$ \\
\hline Assonance & 5 & $5.6 \%$ & $\begin{array}{l}\text { In the video two: entitled How to protect your kids from coronavirus? } \\
\text { In the following example: "Rub Rub and Rub with soap and water for } \\
\text { twenty seconds" (Daily medical information, 2020). }\end{array}$ \\
\hline Total & 25 & $32.5 \%$ & $\begin{array}{l}\text { In the video (4): entitled COVID-Safe \#BacktoSchoolABCs, } \\
\text { assonance has been represented in ABCs are what we need COVID-19 } \\
\text { we will beat (MSFCares, 2020). }\end{array}$ \\
\hline
\end{tabular}


Arab World English Journal (AWEJ) Volume 12. Number 3. September 2021

Agency as Rhetorical Device in the Discourse of kids Animated Learning

Younus \& Kareem

Appendix E: Titles of videos and websites

Appendix D: Repetition figure of speech

\begin{tabular}{|l|l|l|l|}
\hline $\begin{array}{l}\text { Connection figure } \\
\text { of speech }\end{array}$ & Frequency & Percentage & Examples \\
\hline metonymy & 1 & $1.3 \%$ & $\begin{array}{l}\text { In the video four: entitled COVID-Safe \#BacktoSchoolABCs } \\
\text { metonymy is represented in : } \\
\text { "ABCs are what we need". } \\
\text { Singing kids indicate by ABCs: A is for actions they can do. B is } \\
\text { for them to behave, and C is their classrooms (MSFCares, 2020). }\end{array}$ \\
\hline understatement & 3 & $3.9 \%$ & $\begin{array}{l}\text { In the video three: entitled Coronavirus, there is the following: } \\
\text { "I've just known something new about our enemy germs } \\
\text { They can fly } \\
\text { Don't worry if you wear this magical protective mask } \\
\text { When you're walking in a crowd, they can't get into you" (Baby } \\
\text { Toon TV, 2020). }\end{array}$ \\
\hline hyporphora & 1 & $1.3 \%$ & $\begin{array}{l}\text { In the video six: entitled what is Coronavirus? Is: } \\
\text { "Can you guess how many copies of me would fit onto the end of a } \\
\text { tiny in ? Well, the answer is millions and millions of viruses" } \\
\text { (Ineqe Safeguarding Group, 2020). }\end{array}$ \\
\hline Total & 5 & $6.5 \%$ & \\
\hline
\end{tabular}


Arab World English Journal (AWEJ) Volume 12. Number 3. September 2021

\begin{tabular}{|c|c|c|c|}
\hline \multicolumn{4}{|c|}{ Agency as Rhetorical Device in the Discourse of kids Animated Learning } \\
\hline & s of vide & & \\
\hline 1 & $\begin{array}{l}\text { Video } \\
\text { (1) }\end{array}$ & $\begin{array}{l}\text { Coronaviru } \\
\text { s Outbreak } \\
\text { | How did it } \\
\text { start? }\end{array}$ & $\begin{array}{l}\text { https://www.youtube.co } \\
\text { m/watch?v=AahAQkD_ } \\
\text { uQ4 }\end{array}$ \\
\hline 2 & $\begin{array}{l}\text { Video } \\
(2)\end{array}$ & $\begin{array}{l}\text { How to } \\
\text { protect } \\
\text { your kids } \\
\text { from } \\
\text { coronavirus } \\
?\end{array}$ & $\begin{array}{l}\text { https://youtu.be/x83ikJS } \\
\text { 78Lw }\end{array}$ \\
\hline 3 & $\begin{array}{l}\text { Video } \\
\text { (3) }\end{array}$ & $\begin{array}{l}\text { Coronaviru } \\
\mathrm{S}\end{array}$ & $\begin{array}{l}\text { https://youtu.be/- } \\
\text { yNidtlVLEs }\end{array}$ \\
\hline 4 & $\begin{array}{l}\text { Video } \\
\text { (4) }\end{array}$ & $\begin{array}{l}\text { COVID- } \\
\text { Safe \#Back } \\
\text { to School } \\
\text { ABCs }\end{array}$ & $\begin{array}{l}\text { https://youtu.be/iGMJB } \\
\text { ahJXCo }\end{array}$ \\
\hline 5 & $\begin{array}{l}\text { Video } \\
(5)\end{array}$ & $\begin{array}{l}\text { I'm a } \\
\text { Vaccine }\end{array}$ & $\begin{array}{l}\text { https://www.youtube.co } \\
\text { m/watch?v=ITIF-i40dto }\end{array}$ \\
\hline 6 & $\begin{array}{l}\text { Video } \\
(6)\end{array}$ & $\begin{array}{l}\text { What is } \\
\text { Coronaviru } \\
\text { s? }\end{array}$ & $\begin{array}{l}\text { https://www.youtube.co } \\
\text { m/watch?v=FqaXBtSai } \\
\text { UE }\end{array}$ \\
\hline
\end{tabular}

